\title{
Sterol Balance in Man as Plasma Cholesterol Concentrations Are Altered by Exchanges of Dietary Fats *
}

\author{
Norton Spritz, † E. H. Ahrens, Jr., And Scott Grundy \\ (From The Rockefeller Institute, New York, N. Y.)
}

Although the hypocholesteremic effect of unsaturated dietary fats has been repeatedly demonstrated, the mechanism underlying this effect is by no means clear. Four possibilities exist: 1) decreased cholesterol synthesis, 2) increased excretion of cholesterol or its metabolites, or both, 3) shift of plasma cholesterol to some other tissue(s), or 4) some combination of these factors.

In a previous study of a single patient in this hospital (2) significantly increased excretion of neutral but not acidic fecal sterols was demonstrated when unsaturated fat replaced saturated fat in the diet. The present study extends that single experience to five studies in four other patients and utilizes a different and more generally useful methodology.

An adequate evaluation of steroid ${ }^{1}$ excretion depends first on devising a satisfactory procedure for quantitative isolation of fecal neutral steroids and simultaneously of other metabolic end products, notably the fecal bile acids; and second, on measuring accurately these excretion products by means that take into account the numerous chemical forms of these excretion products, some of which are still not identified.

* Submitted for publication March 2, 1965 ; accepted May 20, 1965.

This study was supported in part by U. S. Public Health Service grant HE-06222, National Heart Institute, and in part by U. S. Public Health Service grant no. FR-00102, from the General Clinical Research Centers Branch of the Division of Research Facilities and Resources. This work was reported at the 55th Annual Meeting of the American Society for Clinical Investigation, Atlantic City, N. J., 1963, and has been published in abstract form (1).

$\dagger$ Established Investigator, Health Research Council, New York (I-128). Supported in part by U. S. Public Health Service grant NB-03346-03. Address requests for reprints to Dr. Norton Spritz, Second (Cornell) Medical Division, Bellevue Hospital, New York, N. Y.

1 The term fecal steroid is used in preference to sterol because of the significant amounts of ketonic metabolites of cholesterol that invariably are present in neutral and acidic fractions.

We have attempted to solve these difficult methodological problems as follows: 1) In certain of the studies the sole dietary fat consisted of synthetic glycerides completely free of the sterols that are present in all commercially available, refined dietary oils of natural origin. The feeding of sterolfree fats obviates certain technical and interpretative difficulties: since the intake of sterols is zero, the metabolic products found in the feces must be entirely of endogenous origin, and balance calculations are straightforward. 2) 4-C $\mathrm{C}^{14}$-cholesterol was administered in all five balance studies. Since this resulted in labeling of all of the cholesterol metabolites in the feces, the quantitative aspects of our isolation methods could be documented in each instance and at all stages. 3) Procedures were developed for the quantitative isolation of both the neutral and acidic fecal steroids, as two groups each essentially free of contaminants. The quantities of each group were then determined by weight and by titration, respectively, methods that are all-inclusive and accurate for the multiple forms in which these substances appear in the feces. $^{2}$ Quantitative isolation and measurement are necessitated because colorimetric, precipitation, and certain other nonspecific measurements lead to overestimates if contaminants are present and to underestimates when mixtures of unknown compounds are assayed.

Evidence will be presented to show that in all five studies significant changes in excretion of total fecal steroids did not occur when plasma cholesterol concentrations were altered by exchanges of unsaturated and saturated dietary fats.

Methods
Materials
The dietary fats used in these studies are described
below (Experimental design). All solvents were glass-
2 Later studies $(3,4)$ have demonstrated the superiority
of quantitation of both groups by gas-liquid chromatog-
raphy (GLC).


distilled, diethyl ether over metallic sodium and acetic acid over chromic oxide. Florisil used for column chromatography was 60 to 250 mesh. $^{3}$ Thin-layer plates were prepared according to Mangold (5) ; those used for preparative chromatographs were $0.5 \mathrm{~mm}$ thick and were made of binder-free silicic acid (silica gel $\mathrm{H}$ ) ${ }^{4}$ or Florisil ("finest grade"). Cholesterol-4-C $\mathrm{C}^{\mathbf{1 4}}$ was purified by preparative thin-layer chromatography on silicic acid plates, using heptane : ethyl ether $(1: 1)$ for development.

\section{General methods}

Total fecal radioactivity was determined by the ignition method of Kelly, Peets, Gordon, and Buyske (6). Isotope counting was carried out in a Packard Tri-Carb scintillation counter, using an internal standard for quench correction. Microgravimetric quantitation was carried out in thin glass shells by the method of Craig, Hausmann, Ahrens, and Harfenist (7). Plasma total cholesterol concentration was determined by the method of Abell, Levy, Brodie, and Kendall (8).

\section{Method for neutral and acidic steroids in feces}

During the course of this study, which involved 53 different fecal samples, improvements in methodology were continually being developed, so that our techniques differed somewhat from study to study. In studies 1 and 2 , measurements of neutral and acidic steroids were made on a single extract of fecal homogenate, and the two groups of compounds were separated quantitatively. This proved to be difficult, and in studies 3, 4, and 5 the analyses of the two groups were made on separate samples of the fecal homogenate.

In all five studies in vivo isotopic labeling was accomplished by oral administration of 80 to $100 \mu \mathrm{c}$ of $4-\mathrm{C}^{14}$ cholesterol at least 7 days before the first stool collection. This assured that in each of the studies completeness of recovery could be assured by examination of all residues for unextracted isotopic steroids. In view of more recent improvements in methodology $(3,4)$, isotopic labeling is no longer needed for purposes of quantitation and can be reserved for other experimental purposes.

Homogenization and extraction. Feces collected in 2-quart paint cans were homogenized in a paint shaker after addition of about 1 vol of water and two or three large metal washers. The total weight of the homogenate was recorded to the nearest gram, and a sample of about $10 \mathrm{~g}$ (weighed to the milligram) was taken for extraction of total fecal steroids. After addition of $180 \mathrm{ml}$ acetone and $1 \mathrm{ml}$ of concentrated $\mathrm{HCl}$, the mixtures were boiled under reflux for 48 hours under nitrogen. The extraction mixture was filtered through sharkskin filter paper, ${ }^{6}$ which was then washed with acetone and water. Radioactivity in the residue and in the combined filtrate and washings (about $200 \mathrm{ml}$ ) was determined either by ignition of a weighed sample or by direct counting with

${ }^{3}$ Floridin Co., Hancock, W. Va.

4 Merck \& Co., Rahway, N. J.

5 New England Nuclear Corp., Boston, Mass.

${ }^{6}$ Carl Schleicher \& Schuell Co., Keene, N. H. an internal standard for quench correction. Recovery of isotope in extracts ranged between 89 and $99 \%$ of the total radioactivity determined by combustion in the unextracted sample.

Neutral steroids (studies 3, 4, and 5). The combined filtrate and washes were evaporated and taken up in ethyl ether. Considerable pigmented material was removed from this crude extract by batch adsorption on a 1:1 mixture of Florisil and silicic acid; substances remaining in solution were removed by suction, the adsorbent was washed repeatedly with ether, and the extracts were pooled. A sample of the pooled extract containing approximately $30 \mathrm{mg}$ of mixed solids was then applied in multiple sites along the base of a preparative thin-layer plate of Florisil, which had been prerun with methanol: ethyl ether $(1: 1)$. Cholesterol and coprostanol standards were applied at the two sides of the plate, and the chromatograph was developed for the entire length of the plate $(20 \mathrm{~cm})$ in a system consisting of ethyl ether: heptane $(90: 10)$. In this system the standards had $R_{\mathrm{f}}$ values of approximately 0.40 and 0.50 , respectively, and 95 to $100 \%$ of applied radioactivity was recovered in bands corresponding to these standards. But, in addition, there were faint bands with $R_{r}$ values slightly faster than coprostanol and slightly slower than cholesterol. Further study by GLC has indicated that each of the four bands is a complex mixture of fecal steroids; qualitative aspects will be considered in a separate report (4). For present purposes the steroids in all four bands were quantitatively recovered as one fraction by removal of the appropriate area of the adsorbent according to Goldrick and Hirsch (9) and desorption with ethyl ether. Total steroid content of each specimen was then determined microgravimetrically on a sample of this water-clear solution containing a minimum of $1 \mathrm{mg}$ of steroids.

In stool samples of three subjects on sterol-free diets, excellent agreement between the specific activities of

TABLE I

Comparisons between specific activities of plasma cholesterol and fecal steroid fractions (4-C $C^{14}$. cholesterol administered by mouth to three patients on sterol-free diets)

\begin{tabular}{|c|c|c|c|c|}
\hline \multirow[b]{2}{*}{ Study } & \multirow{2}{*}{$\begin{array}{l}\text { Days } \\
\text { after } \\
\text { isotope } \\
\text { adminis- } \\
\text { tration }\end{array}$} & \multicolumn{3}{|c|}{ Specific activities } \\
\hline & & $\begin{array}{c}\text { Plasma } \\
\text { choles- } \\
\text { terol }\end{array}$ & $\begin{array}{l}\text { Neutral } \\
\text { steroids }\end{array}$ & $\begin{array}{l}\text { Acidic } \\
\text { steroids }\end{array}$ \\
\hline & & \multicolumn{3}{|c|}{ cpm/umole } \\
\hline 1 & $\begin{array}{r}6 \\
8 \\
14\end{array}$ & $\begin{array}{r}107 \\
81 \\
49\end{array}$ & $\begin{array}{r}102 \\
84 \\
52\end{array}$ & $\begin{array}{l}56 \\
78 \\
52\end{array}$ \\
\hline 3 & $\begin{array}{r}7 \\
14 \\
27\end{array}$ & $\begin{array}{r}204 \\
76 \\
57\end{array}$ & $\begin{array}{r}199 \\
80 \\
57\end{array}$ & $\begin{array}{r}190 \\
67 \\
54\end{array}$ \\
\hline 4 & $\begin{array}{r}9 \\
12 \\
17 \\
28\end{array}$ & $\begin{array}{r}220 \\
144 \\
118 \\
86\end{array}$ & $\begin{array}{r}170 \\
140 \\
110 \\
84\end{array}$ & $\begin{array}{r}38 \\
42 \\
110 \\
77\end{array}$ \\
\hline
\end{tabular}




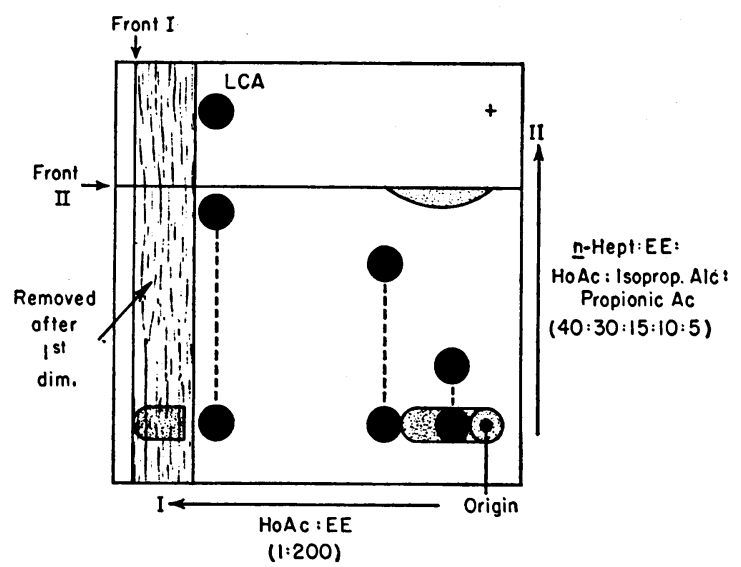

Fig. 1. Schematic Representation of 2-Dimensional PREPARATIVE THIN-LAYER CHROMATOGRAPHY OF FECAL BILE ACIDS. Shaded area between Front I and LCA (lithocholic acid standard) contains contaminants and is removed after plate is run in first dimension. Trisubstituted group of bile acids lies nearest to origin, monosubstituted group nearest to LCA, and disubstituted group between them. Second dimension-heptane: ethyl ether: acetic acid : isopropyl alcohol: propionic acid.

plasma cholesterol and total neutral fecal steroids was attained 6,7 , and 12 days, respectively, after oral administration of $4-\mathrm{C}^{\mathbf{1 4}}$-cholesterol (Table I). The similarity of specific activities of these fractions, after attainment of equilibrium, is taken as evidence for the absence of nonsteroid contaminants in final extracts from the thin-layer chromatoplates: the presence of contaminating unlabeled substances would have lowered the specific activities of the isolated fractions. Furthermore, the similarity of these specific activities after attainment of equilibrium demonstrated convincingly that the fecal neutral steroids must have been derived from pools in equilibrium with plasma cholesterol, and that no unlabeled cholesterol pools contributed significantly to the fecal neutral steroids.

Gravimetric determination of fecal neutral steroids in stool samples of patients on sterol-containing diets is valid only when a correction is made for exogenous sterol intake. In the present procedure this is accomplished by use of plasma cholesterol specific activity data (see below, Calculation, in section on Experimental design).

Acidic steroids (studies 3, 4, and 5). The acetone extract used for bile acid analysis was evaporated to a syrup, then dissolved in $50 \mathrm{ml}$ of $\mathrm{N} \mathrm{NaOH}$. This mixture was heated to $120^{\circ}$ for 2 hours in a pressure cooker (15 pounds per square inch); these conditions were shown by Levin, Irvin, and Johnston (10) and confirmed by us to be required for hydrolysis of taurine and glycine conjugates of cholic and chenodeoxycholic acids. A hydrolysis step is necessitated by the presence in some specimens of feces of variable amounts of conjugated acids, but it serves also to degrade some of the fecal pigments, permitting easier removal of these contaminating acids from the bile acids. Tests on $24-C^{14}$-bile acids subjected to this hydrolysis procedure showed no degradation to other compounds (as judged by thin-layer chromatography) or destruction of the side-chain (as evidenced by specific activity measurements).

After hydrolysis the mixture was applied in the smallest possible volume of acetone to a $15-\mathrm{g}$ Florisil column. Elution with $100 \mathrm{ml} n$-heptane followed by $150 \mathrm{ml}$ of $1 \%$ $n$-propionic acid in $n$-heptane removed all neutral sterols and other nonsaponifiable materials, as well as nonhydroxylated free fatty acids. Studies with $24-C^{14}-$ lithocholic acid showed that less than $2 \%$ of this nonpolar bile acid was eluted with these solvents. The bile acids were then eluted as a group with $250 \mathrm{ml}$ acetic acid: ethyl ether (1:9). Completeness of elution was demonstrated in tests with in vivo labeled acids as well as with test solutions containing $24-\mathrm{C}^{14}$-cholic acid. The eluate was now faintly yellow, most of the contaminating pigments having been retained on the column.

Final purification of the bile acid fraction was carried out by two-dimensional thin-layer chromatography on silicic acid $(0.5 \mathrm{~mm})$. The bile acid solution off the Florisil column was evaporated to dryness and taken up to $25 \mathrm{ml}$ with ethyl acetate. A 5-ml sample of this solution, containing approximately $2 \mathrm{mg}$ of bile acids, was applied in a single spot at the lower left-hand corner of the plate (Figure 1), and a standard solution of lithocholic acid at the lower right-hand corner. The plate was developed for its entire length $(20 \mathrm{~cm})$ in acetic acid: ethyl ether $(1: 200)$, dried, and stained with iodine vapor, and that portion beyond lithocholic acid was scraped off and discarded. In experiments with in vivo labeled bile acids this pigmented discard never contained more than $10 \%$ of applied radioactivity, but its removal from the plate before development of the second dimension was found to be essential in preventing contamination of the lithocholic zone of the plate. The plate was then developed in the second dimension with heptane: ethyl ether: acetic acid : isopropyl alcohol : propionic acid ( $40: 30: 15: 10: 5)$, dried, and stained with iodine vapor. The area containing bile acids extended diagonally from a spot corresponding to cholic acid to the lithocholic acid spot at the juncture of the two solvent fronts (Figure 1). All adsorbent in the bile acid area was collected in a $40-\mathrm{ml}$ glass-stoppered test tube, and $10 \mathrm{ml}$ water and $20 \mathrm{ml}$ ethyl acetate were added with a crystal of sodium thiosulfate. After equilibration the upper phase contained bile acids; inorganic solutes, including calcium sulfate and iodide ions, remained in the lower phase. The upper phase was quantitatively recovered and made to volume with ethyl acetate. A sample of this colorless solution of bile acids was titrated in $50 \%$ ethanol with $0.02 \mathrm{~N} \mathrm{NaOH}$, and results were expressed as milligrams of bile acids, with the molecular weight of deoxycholic acid (393) used.

In most fecal specimens, material with chromatographic characteristics of cholic acid was not observed. Qualitative studies by GLC, to be reported separately (3), revealed that the bile acids recovered from the mono-, di-, and trisubstituted bile acid zones on the preparative chromatoplate were complex mixtures of many components, 
TABLE II

Purity of final preparation of fecal bile acids; total bile acids and component fractions isolated by thin-layer chromatography [4-C ${ }^{14}$-cholesterol administered by mouth 23 days (specimen 1) and 32 days (specimen 2) previously]

\begin{tabular}{|c|c|c|}
\hline \multirow[b]{2}{*}{ Fraction } & \multicolumn{2}{|c|}{ Specific activities } \\
\hline & Specimen 1 & Specimen 2 \\
\hline & \multicolumn{2}{|c|}{ cpm/umole } \\
\hline $\begin{array}{l}\text { Total fraction } \\
\text { Monosubstituted group } \\
\text { Disubstituted group } \\
\text { Trisubstituted group }\end{array}$ & $\begin{array}{c}27 \\
25 \\
23 \\
\text { Not present }\end{array}$ & $\begin{array}{l}56 \\
58 \\
60 \\
54\end{array}$ \\
\hline
\end{tabular}

some as yet not identified. For present purposes, however, the mixed bile acids were quantified as a group by titration. That the final solution can be nearly free of contaminants was shown by close agreement between specific activities of the entire fraction and of subfractions (Table II).

Another indication of purity of the bile acid fractions was obtained by comparing specific activities of plasma cholesterol and fecal bile acids (Table I). Since previous studies (11) have indicated that a correlation exists between the specific activities of plasma cholesterol and of biliary bile acids after the administration of labeled cholesterol, it seems reasonable to assume that fecal bile acid specific activities would be closely related to those of plasma cholesterol. Indeed, in the present study there was good agreement between fecal bile acid and plasma cholesterol specific activities after equilibrium periods varying from 7 days in study 3 to 17 days in study 4 . (The slightly lower specific activity of fecal bile acids may reflect small amounts of contaminants. Nevertheless, the degree of contamination of the bile acid fraction in the present studies, if any, causes only a small error in the estimate of total fecal steroids, since this fraction amounts to only about one-quarter of the total fecal steroids.)

Subsequent refinements of this method, to be published separately (3), have indicated that the quantitation of bile acids can be carried out more reliably by GLC than by titration; however, the daily excretion rates determined by the newer method agree closely with those reported in the present study.

Quantitative separation of neutral from acidic steroids (studies 1 and 2). In study 1 the neutral and acidic steroids in the primary crude extract were cleanly separated from each other by countercurrent distribution $(n=15)$ as previously described (12), and in study 2 by column chromatography on Florisil. In the latter case, the neutral steroids were eluted from a $15-\mathrm{g}$ column with ethyl ether or $1 \% n$-propionic acid in heptane. Although the fraction was heavily contaminated with other nonpolar substances, labeled cholesterol was quantitatively recovered in these eluates, and the most nonpolar bile acid, lithocholic, was selectively retained on the column. Mixed bile acids were then eluted with acetic acid : water : methanol $(1: 1: 8)$. The bile acid-containing eluate was still contaminated with pigments, but taurocholic acid was eluted quantitatively, as were all less polar conjugated and free bile acids. Completeness of recoveries was verified in every sample by measuring isotopic materials applied and eluted. In study 2 subsequent purification of the two eluates and final measurement of neutral and acidic steroids were then carried out as in experiments 3,4 , and 5 . The method utilized in study 1 is published elsewhere (12).

\section{Determination of fecal excretion rate}

The rates at which feces were excreted were determined by administering an inert material, chromium oxide $\left(\mathrm{Cr}_{2} \mathrm{O}_{3}\right)$, as internal standard, as described by Stanley and Cheng (13) and Whitby and Lang (14). Patients received $60 \mathrm{mg}$ of $\mathrm{Cr}_{2} \mathrm{O}_{3}$ in capsules with each of their five daily formula feedings throughout the study. At the same time that samples of fecal homogenates were taken for extraction of neutral and acidic steroids, other weighed samples were taken for measurement of chromium content. Duplicates agreed within $\pm 5 \%$.

The advantage of the chromic oxide procedure is that fecal excretion rates of individual components can be accurately estimated when stool collections are incomplete or of short duration; furthermore, feces collections made on a calendar basis can be corrected to a true 24-hour (or multiple) figure. In our hands the method was validated in two ways. 1) After a single oral dose of chromic oxide $(300 \mathrm{mg}), 97.5 \%$ was recovered in the stool in the succeeding 96 hours. 2) In a second patient to whom the indicator was given five times a day for 10 days as described above, stool specimens were collected daily for the last 5 days and weighed. Then, the fecal flow rate was determined for each day on the basis of $\mathrm{Cr}_{2} \mathrm{O}_{3}$ measurements. By the latter method the total 5-day excretion of feces was calculated to be $423 \mathrm{~g}$; the actual weight of feces during this period was $410 \mathrm{~g}$, a difference of $3 \%$.

\section{Experimental design}

The age, sex, and clinical diagnoses of the four patients studied are listed in Table III. (Patient J. Mc. was studied through two different pairs of fat exchangesstudies 3 and 5). Patients were hospitalized in a metabolic ward for the 3 to 6 months involved in each of the studies.

During this period their food intakes consisted exclusively of orally administered liquid feedings in which dietary fat contributed $40 \%$, protein $15 \%$, and glucose $45 \%$ of total caloric intake; vitamin and mineral supplements were also given, as previously described (15). Total caloric intake was adjusted in every case to avoid weight change.

The fatty acid compositions and sterol contents of all dietary fats are described in Table IV. In three studies (no. 1, 3, and 4) the fats consisted solely of sterol-free triglycerides, synthesized from glycerol and pure fatty acids. ${ }^{7}$ In studies 3 and 4 the synthetic fats were very

7 These "synthetic fats" were generously provided by Dr. F. M. Mattson, Proctor and Gamble Co., Cincinnati, Ohio. 
TABLE III

Clinical data

\begin{tabular}{|c|c|c|c|c|c|c|c|}
\hline $\begin{array}{l}\text { Study } \\
\text { no. }\end{array}$ & Initials & Age & Sex & Diagnosis & $\begin{array}{l}\text { Duration } \\
\text { of study }\end{array}$ & $\begin{array}{l}\text { Caloric } \\
\text { intake }\end{array}$ & $\begin{array}{c}\text { Fat in } \\
\text { take }\end{array}$ \\
\hline & & $y r s$ & & & wks & $\mathrm{cal} / d a y^{*}$ & $g / d a y t$ \\
\hline 1 & R.C. & 44 & $\mathrm{~F}$ & $\begin{array}{l}\text { Familial hyper- } \\
\text { cholesteremia } \\
\text { and hypergly- } \\
\text { ceridemia }\end{array}$ & 12 & 2,000 & 89 \\
\hline 2 & M.S. & 58 & $\mathrm{~F}$ & $\begin{array}{l}\text { Familial hyper- } \\
\text { cholesteremia } \\
\text { and hypergly- } \\
\text { ceridemia }\end{array}$ & 9 & 2,031 & 90 \\
\hline 3 & J.Mc. & 50 & $\mathbf{M}$ & Normal & 8 & 2,000 & 89 \\
\hline 4 & J.G. & 40 & $\mathbf{M}$ & $\begin{array}{l}\text { Familial hyper- } \\
\text { cholesteremia } \\
\text { and hypergly- } \\
\text { ceridemia }\end{array}$ & 16 & 3,125 & 139 \\
\hline 5 & J.Mc. & 50 & $\mathbf{M}$ & Normal & 12 & 2,188 & 97 \\
\hline
\end{tabular}

* Required to maintain constant body weight.

$\dagger$ Fat calories $=40 \%$ of total calories.

similar in composition to commercial coconut and corn oils: they differed from each other markedly in chain length and in degree of saturation of the component fatty acids. By contrast, in study 1 the experiment was carried out with two synthetic triglycerides that were composed of fatty acids of similar chain length but markedly different in degree of saturation, respectively, linoleic acid (LLL) and palmitic and oleic acids $(P / O)$. In studies 2 and 5 commercially available, refined sterolcontaining fats were fed.

Figure 2 depicts plasma cholesterol concentrations in all subjects during their study and illustrates the three metabolic periods during which collections of feces were made. Period I began after plasma cholesterol concen- trations had stabilized on the first of the two dietary fats under test and lasted until the institution of the second fat. During the last 6 to 16 days of period I feces were collected intermittently. Period II began with the institution of the second dietary fat and persisted throughout a transitional period (defined as that time during which changes in plasma cholesterol concentration occurred). During period II (which varied from 4 to 12 days in the five studies) complete stool collections were made in 2- to 4-day pools. Period III lasted for 5 to 20 days after cholesterol concentrations had stabilized on feeding the second fat; stool collections were again intermittent, as in the first period.

Cholesterol-4- $\mathrm{C}^{\mathbf{1 4}}$ was administered orally during the

TABLE IV

Dietary fats fed in five sterol balance studies; fatty acid and sterol compositions

\begin{tabular}{|c|c|c|c|c|c|c|c|c|c|c|c|c|}
\hline \multirow[b]{2}{*}{ Fat } & \multicolumn{9}{|c|}{ Fatty acid composition (weight percentages) } & \multirow{2}{*}{$\begin{array}{l}\text { Iodine } \\
\text { value }\end{array}$} & \multirow{2}{*}{$\begin{array}{l}\text { Total } \\
\text { sterol } \\
\text { content }\end{array}$} & \multirow{2}{*}{$\begin{array}{l}\text { Fed in } \\
\text { study no. }\end{array}$} \\
\hline & $8: 0$ & $10: 0$ & $12: 0$ & $14: 0$ & $16: 0$ & $16: 1$ & $18: 0$ & $18: 1$ & $18: 2$ & & & \\
\hline & & & & & & & & & & & $m g / 100 \mathrm{~g}$ & \\
\hline $\begin{array}{c}\text { A. "Synthetic" } \\
\text { corn oil* }\end{array}$ & & & & & 12.1 & & 1.8 & 30.0 & 55.6 & 127 & 0 & 3 and 4 \\
\hline $\begin{array}{l}\text { B. "Synthetic" } \\
\text { coconut oil* }\end{array}$ & 3.6 & 5.0 & 42.4 & 22.7 & 11.0 & & 3.7 & 8.9 & 2.8 & 8 & $\mathbf{0}$ & 3 and 4 \\
\hline C. Trilinolein* & & & & & 0.9 & & & 1.5 & 96.6 & 171 & $\mathbf{0}$ & 1 \\
\hline $\begin{array}{l}\text { D. Palmitic-oleic } \\
\text { glycerides* } \\
(\mathrm{P} / \mathrm{O})\end{array}$ & & & & & 45.6 & & & 52.8 & & 、 46 & $\mathbf{0}$ & 1 \\
\hline $\begin{array}{l}\text { E. Commercial } \\
\text { corn oil } t\end{array}$ & & & & & 13.1 & & 2.2 & 30.0 & 54.8 & 126 & 975 & 2 and 5 \\
\hline $\begin{array}{l}\text { F. Commerical } \\
\text { coconut oil }\end{array}$ & 4.5 & 6.9 & 43.8 & 24.9 & 10.4 & & 2.3 & 5.7 & 1.7 & 8 & 68 & 2 and 5 \\
\hline
\end{tabular}

* Prepared by Dr. F. H. Mattson, Procter and Gamble Co., Cincinnati, Ohio.

$\dagger$ Mazola, Corn Products Refining Co., New York, N. Y.

$\mp$ E. F. Drew and Co., New York, N. Y. 


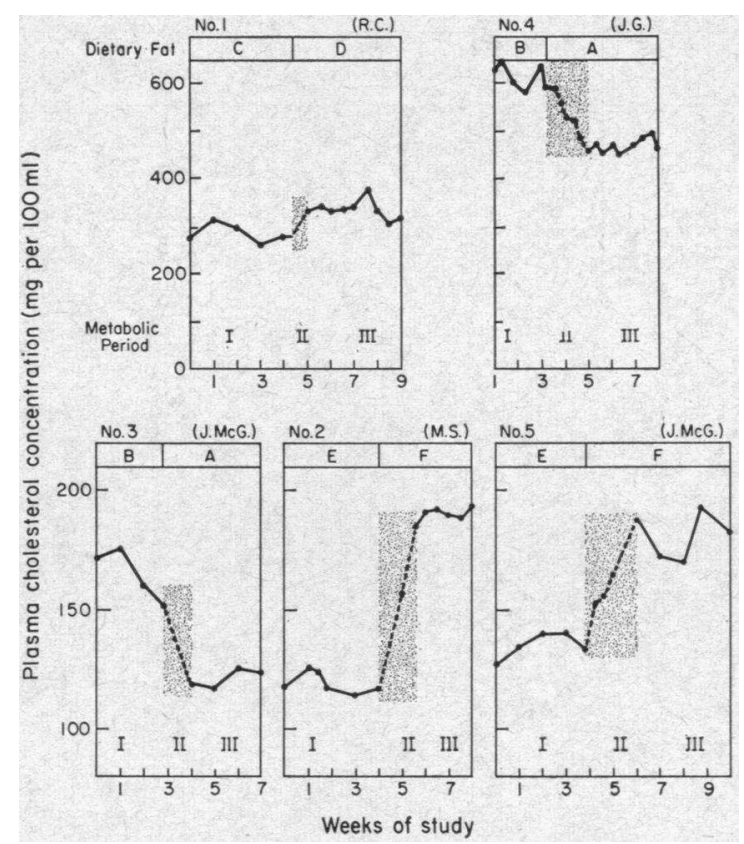

Fig. 2. Plasma cholesterol changes in five studies OF FECAL STEROID EXCRETION. Dietary fats are lettered as in Tables IV and V. Period II (shaded) = transition state between steady states I and III.

first period; a concentrated solution in ethanol was suspended in approximately $50 \mathrm{ml}$ of water, which was then well mixed in a single formula feeding. The first stools were not collected until 7 days or more later, in order to permit equilibration of ingested radioactive cholesterol with readily exchangeable cholesterol pools.

Calculation of fecal excretion rate of neutral and acidic sterols. Recoveries of labeled neutral and acidic steroids through all procedural steps exceeded $95 \%$ in studies 3,4 , and 5 , but in studies 1 and 2 losses up to $20 \%$ were encountered. However, it was possible to correct for these losses, having in hand the total isotope excretion data and the specific activities of plasma cholesterol at corresponding times. Calculations from these data were validated by the close agreement between the specific activities of plasma cholesterol and fecal steroids (both neutral and acidic) in studies of patients on sterol-free diets.

Daily excretion rates were calculated on the basis of $\mathrm{Cr}_{2} \mathrm{O}_{3}$ data by the following formula:

[daily intake of $\mathrm{Cr}_{2} \mathrm{O}_{3}$ (milligrams)/milligrams $\mathrm{Cr}_{2} \mathrm{O}_{3}$ per gram of fecal homogenate] $\times$ [milligrams of total fecal steroids (neutral or acidic)/grams of fecal homogenate] = daily excretion (milligrams).

In studies 2 and 5 unabsorbed exogenous plant sterols were included in the final fecal neutral steroid fraction along with the endogenous steroids; they were, of course, unlabeled. Amounts of endogenous steroids were readily calculated, however, from the available isotope data. Thus, the endogenous neutral steroids of the feces $=$ disintegrations per minute of the fecal neutral steroid frac- tion divided by specific activity of plasma cholesterol at that time.

In study 2 total neutral steroids also were determined gravimetrically. During corn oil ingestion (period I) exogenous plant sterols intake approximated $1,000 \mathrm{mg}$ per day, and the daily fecal output of plant sterols and their metabolic products (calculated from isotope data as total minus endogenous neutral steroids) averaged $960 \mathrm{mg}$ per day, indicating negligible retention of plant sterols.

\section{Results}

In five balance studies on four patients, excretion rates were determined on 53 fecal specimens, each representing 1 to 4 days' collection or a total of 122 daily excretions.

The following questions were considered: 1) Can changes in plasma cholesterol content produced by exchanges of dietary fats be accounted for by alterations in the excretion of cholesterol and/or its neutral and acidic metabolic end products? 2) What are the relative effects of dietary sterol and fatty acid saturation on plasma cholesterol concentration and on the fecal excretion of neutral and acidic steroids?

Plasma cholesterol changes and fecal excretion rates. Table $\mathrm{V}$ lists the mean plasma cholesterol concentrations and total steroid excretions during the three experimental periods in the five separate studies. In each instance a significant change in plasma concentration occurred; this was calculated to represent a change in plasma content varying from 1,317 to $6,437 \mathrm{mg}$. If these changes were due to changes in fecal excretion of cholesterol and its metabolic products during period II, increased or decreased excretion rates varying from -155 to $+585 \mathrm{mg}$ per day should have been found. Table V shows, however, that the differences in excretion rates among the experimental periods were not significant in any of the five studies. Indeed, in study 1 in which the plasma cholesterol content increased, the excretion of fecal steroids during period II exceeded that of period I. In studies 2,3 , and 4 , the excretion of total fecal steroids in periods I and II differed by less than $1 \mathrm{SD}$.

Considerable daily variation in fecal steroid excretion rates occurred in most patients, as evidenced by the relatively high standard deviations around the averages for each period. The question was then asked: Was the magnitude of the change in fecal steroid excretion that was postu- 
TABLE V

Five sterol balance studies during exchanges

\begin{tabular}{|c|c|c|c|c|c|c|c|}
\hline \multirow[b]{2}{*}{$\begin{array}{c}\text { Study } \\
\text { no. }\end{array}$} & \multicolumn{2}{|c|}{ Dietary fats* } & \multirow{2}{*}{$\begin{array}{c}\text { Body } \\
\text { weight } \\
\text { (mean and } \\
\text { range) }\end{array}$} & \multirow[b]{2}{*}{$\begin{array}{l}\text { Plasma } \\
\text { volume }\end{array}$} & \multicolumn{2}{|c|}{$\begin{array}{l}\text { Plasma cholesterol } \\
\text { Mean } \pm \text { SD }\end{array}$} & \multirow{2}{*}{$\begin{array}{c}\text { Change in } \\
\text { plasma } \\
\text { cholesterol } \\
\text { content }\end{array}$} \\
\hline & $\underset{I}{\text { Period }}$ & $\begin{array}{c}\text { Period } \\
\text { II }+ \\
\text { III }\end{array}$ & & & $\overline{\substack{\text { Period } \\
\text { I }}}$ & $\underset{\text { III }}{\text { Period }}$ & \\
\hline & & & $k g$ & $m l$ & \multicolumn{2}{|c|}{$\mathrm{mg} / 100 \mathrm{ml}$ plasma } & $m g$ \\
\hline$\stackrel{1}{\text { R.C. }}$ & $\mathrm{C}$ & D & $\begin{array}{c}58.5 \\
(58.0- \\
59.2)\end{array}$ & 2,635 & $\begin{array}{l}286 \\
\pm 17.6 \\
(5)\end{array}$ & $\begin{array}{l}340 \\
\pm 20 \\
(9)\end{array}$ & $+1,422$ \\
\hline$\stackrel{2}{\text { M.S. }}$ & $\mathbf{E}$ & $\mathrm{F}$ & $\begin{array}{c}53.3 \\
(53.0- \\
53.6)\end{array}$ & 2,400 & $\begin{array}{l}119 \\
\pm 4.3 \\
(6)\end{array}$ & $\begin{array}{l}190 \\
\pm 2.8 \\
(6)\end{array}$ & $+1,705$ \\
\hline$\stackrel{3}{\text { J.Mc. }}$ & B & A & $\begin{array}{c}68.0 \\
(67.8- \\
69.2)\end{array}$ & 3,060 & $\begin{array}{l}165 \\
\pm 11.0 \\
(4)\end{array}$ & $\begin{array}{l}122 \\
\pm 5.0 \\
(4)\end{array}$ & $-1,317$ \\
\hline$\stackrel{4}{\text { J.G. }}$ & B & A & $\begin{array}{c}93.5 \\
(93.2- \\
93.7)\end{array}$ & 4,210 & $\begin{array}{l}615 \\
\pm 25.2 \\
(6)\end{array}$ & $\begin{array}{l}462 \\
\pm 8.7 \\
(6)\end{array}$ & $-6,435$ \\
\hline$\stackrel{5}{\text { J.Mc. }}$ & $\mathrm{E}$ & $\mathrm{F}$ & $\begin{array}{c}68.5 \\
(67.8- \\
68.8)\end{array}$ & 3,060 & $\begin{array}{l}137 \\
\pm 3.5 \\
(4)\end{array}$ & $\begin{array}{l}180 \\
\pm 9.6 \\
(5)\end{array}$ & $+1,317$ \\
\hline
\end{tabular}

* See Table IV for dietary fat compositions.

$\dagger$ Estimated as $4.5 \%$ of total body weight (16).

$\mp$ Change in plasma cholesterol content divided by number of days in period II.

$\S$ Excretion rate predicted on basis that entire change in plasma cholesterol content resulted from altered excretion of steroids in feces- thus, period I excretion plus or minus postulated change in excretion.

II (6:3) means 6 days represented by 3 complete stool collections.

if Endogenous sterols only (see Methods: Calculation).

lated to explain the increased or decreased plasma cholesterol contents during period II sufficiently large to have been detected reliably in the face of this large day-to-day variation? To answer this question, the actual excretion rates during period II were compared to those hypothesized to produce such changes. (Hypothetical excretion rates were calculated as mean excretion rates of period I plus or minus the postulated change in excretion per day. For statistical analysis of the difference between actual and hypothetical excretion rates, the standard deviation proportional to that actually observed in period II was used, or the standard deviation of the actual period II excretion, whichever was larger.) The actual and hypothetical excretions in period II are listed in Table V, and the significance of the differences (by Student's $t$ test) is listed in the last column. In three of the five studies the differences were significant, that is, despite the variations in daily excretion rates, the hypothesized change in excretion could have been detected.

We conclude from these studies that in no instance did a significant change in fecal steroid ex- cretion actually occur simultaneously with a change in plasma cholesterol concentration. In three of five studies there was less than a 5\% possibility that altered fecal excretions of steroids, large enough to explain the plasma changes, were not detected because of variations in day-to-day excretions.

Dietary sterol vs. degree of saturation. Plasma cholesterol concentrations during the ingestion of saturated fats ranged from 1.19 to 1.60 times those found on the unsaturated fat regimens, whether or not the dietary fats contained sterols (Table VI). Although the greatest change occurred in study 2 , when commercial coconut replaced commercial corn oil (both fats containing plant sterols), our data are too few to permit any conclusion whether dietary sterols (at this level of intake) materially influence plasma cholesterol concentrations. Indeed, in J. Mc. who was studied twice (studies 3 and 5), the plasma cholesterol concentration was equally elevated on both diets containing coconut glycerides, whether plant sterols were present or absent from the dietary fat. 
of saturated and unsaturated dietary fats

\begin{tabular}{|c|c|c|c|c|c|c|c|}
\hline \multicolumn{3}{|c|}{$\begin{array}{l}\text { Fecal excretion of total steroids } \\
\text { Mean } \pm S D\end{array}$} & \multirow{2}{*}{$\begin{array}{l}\text { Significance of } \\
\text { differences be- } \\
\text { tween periods } \\
\text { I, II, and III }\end{array}$} & \multirow{2}{*}{$\begin{array}{c}\text { Length } \\
\text { of } \\
\text { period } \\
\text { II }\end{array}$} & \multirow{2}{*}{$\begin{array}{l}\text { Postulated } \\
\text { change in } \\
\text { excretion } \ddagger\end{array}$} & \multirow{2}{*}{$\begin{array}{l}\text { Hypothetical } \\
\text { total ex- } \\
\text { cretion in } \\
\text { period II }\end{array}$} & \multirow{2}{*}{$\begin{array}{l}\text { Significance of } \\
\text { differences: actual } \\
\text { vs. hypothetical } \\
\text { excretion in } \\
\text { period II ( } t \text { test) }\end{array}$} \\
\hline$\underset{I}{\text { Period }}$ & $\underset{\text { III }}{\text { Period }}$ & $\begin{array}{l}\text { Period } \\
\text { III }\end{array}$ & & & & & \\
\hline $\begin{array}{l}433 \\
\pm 44 \\
(6: 3) \|\end{array}$ & $\begin{array}{l}m g / \text { day } \\
613 \\
\pm 147 \\
(4: 2)\end{array}$ & $\begin{array}{l}355 \\
\pm 132 \\
(5: 3)\end{array}$ & $\begin{array}{c}\text { NS } \\
\text { by analysis } \\
\text { of variance }\end{array}$ & $\begin{array}{c}\text { days } \\
4\end{array}$ & $\begin{array}{r}m g / d a y \\
-373\end{array}$ & $\begin{array}{l}m g / d a y \\
60 \\
\pm 147\end{array}$ & $\mathrm{p}<0.05$ \\
\hline $\begin{array}{l}843 \pi \\
\pm 162 \\
(9: 4)\end{array}$ & $\begin{array}{l}843 \\
\pm 178 \\
(11: 3)\end{array}$ & $\begin{array}{l}758 \\
\pm 121 \\
(16: 4)\end{array}$ & NS & 11 & -155 & $\begin{array}{l}688 \\
\pm 178\end{array}$ & NS \\
\hline $\begin{array}{l}658 \\
\pm 26 \\
(6: 3)\end{array}$ & $\begin{array}{l}657 \\
\pm 42 \\
(8: 4)\end{array}$ & $\begin{array}{l}666 \\
\pm 43 \\
(5: 4)\end{array}$ & NS & 8 & +145 & $\begin{array}{l}803 \\
\pm 52\end{array}$ & $\mathrm{p}<0.01$ \\
\hline $\begin{array}{l}729 \\
\pm 125 \\
(9: 4)\end{array}$ & $\begin{array}{l}713 \\
\pm 96 \\
(11: 4)\end{array}$ & $\begin{array}{l}835 \\
\pm 86 \\
(11: 4)\end{array}$ & NS & 11 & +585 & $\begin{array}{l}1,314 \\
\pm 177\end{array}$ & $\mathrm{p}<0.002$ \\
\hline $\begin{array}{l}7919 \\
\pm 59 \\
(6: 4)\end{array}$ & $\begin{array}{l}714 \\
\pm 80 \\
(10: 4)\end{array}$ & $\begin{array}{l}824 \\
\pm 199 \\
(5: 3)\end{array}$ & NS & 10 & -132 & $\begin{array}{l}659 \\
\pm 80\end{array}$ & NS \\
\hline
\end{tabular}

Table VII depicts the data from the five studies pooled according to saturation of the dietary fat and to its content of dietary sterols. The excretion rates of acidic, neutral, and total steroids are tabulated separately. Dietary plant sterols significantly increased bile acid excretion, whether the dietary fats were saturated or unsaturated. On saturated fat regimens bile acid excretion averaged $101 \pm 50 \mathrm{mg}$ per day in 12 specimens obtained when sterol-free fats were fed, as opposed to $247 \pm 70 \mathrm{mg}$ with sterol-containing fats. During unsaturated fat regimens bile acid excretion averaged $134 \pm 54 \mathrm{mg}$ per day with ingestion of sterol-free fats, in contrast to $271 \mathrm{mg}$ with ingestion of sterol-containing fats.
On the other hand, endogenous neutral steroid excretion was not significantly affected either by the presence or absence of dietary sterols or by the degree of saturation of the dietary fat. Mean excretions varied between $498 \pm 185 \mathrm{mg}$ per day with the ingestion of saturated sterol-free fats to $538 \pm 137$ on sterol-free unsaturated fats.

These differences in excretion rates affecting acids but not neutral fecal steroids suggest that these two pathways of cholesterol excretion are controlled by separate factors. An analysis of acidic and neutral sterol excretion rates in the 53 specimens that form the basis of these studies (Figure 3) illustrates their independent variation, further supporting this idea.

TABLE VI

Changes in plasma cholesterol concentrations on saturated vs. unsaturated dietary fats

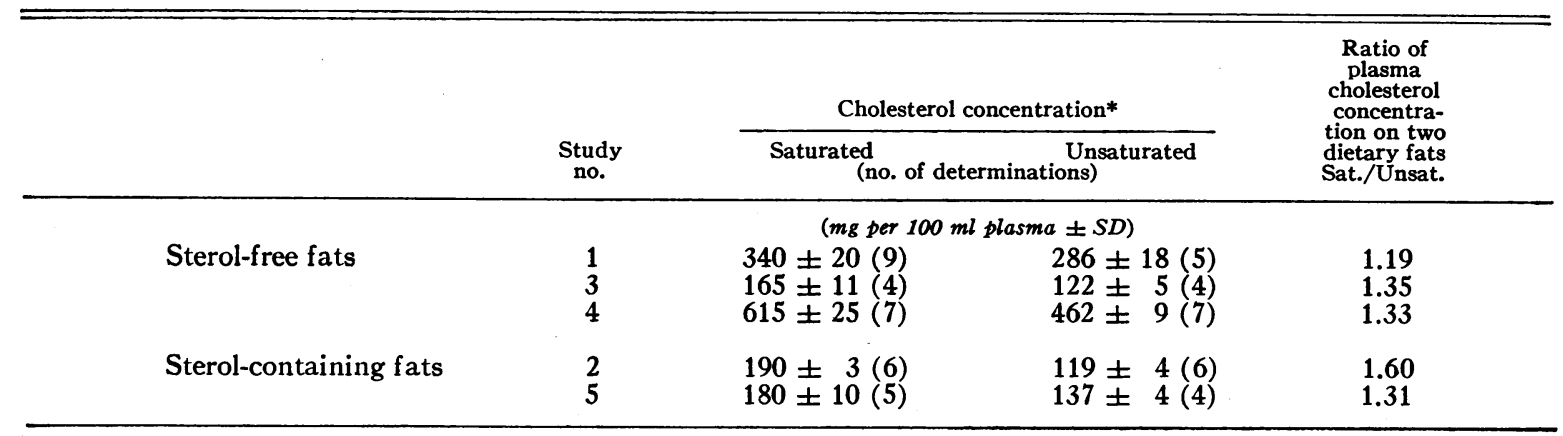

* Values obtained during steady states (periods I and III). 
TABLE VII

Changes in dietary sterols compared to changes in dietary fatty acids; effects on excretions of acidic and neutral steroids in feces (raw data from five studies pooled)

\begin{tabular}{|c|c|c|c|c|c|c|c|c|c|c|c|c|c|}
\hline & \multirow{2}{*}{\multicolumn{2}{|c|}{$\begin{array}{c}\begin{array}{c}\text { No. of } \\
\text { days of } \\
\text { study }\end{array} \\
\begin{array}{c}\text { Dietary } \\
\text { sterols }\end{array}\end{array}$}} & \multirow{2}{*}{\multicolumn{2}{|c|}{ 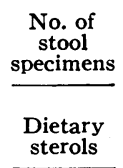 }} & \multicolumn{3}{|c|}{ Bile acid excretion } & \multicolumn{3}{|c|}{$\begin{array}{l}\text { Excretion of endogenous } \\
\text { neutral steroids }\end{array}$} & \multicolumn{3}{|c|}{$\begin{array}{l}\text { Excretion of total } \\
\text { endogenous steroids }\end{array}$} \\
\hline & & & & & \multicolumn{2}{|c|}{ Dietary sterols } & \multirow{2}{*}{$\begin{array}{c}\text { Statistical } \\
\text { significance } \\
\text { Diet sterols + } \\
\text { vs. } \\
\text { diet sterols - }\end{array}$} & \multicolumn{2}{|c|}{ Dietary sterols } & \multirow{2}{*}{$\begin{array}{c}\text { Statis- } \\
\text { tical } \\
\text { signifi- } \\
\text { cance } \\
(+ \text { vs. }-)\end{array}$} & \multicolumn{2}{|c|}{ Dietary sterols } & \multirow{2}{*}{$\begin{array}{c}\text { Statistical } \\
\text { significance } \\
(+ \text { vs. }-)\end{array}$} \\
\hline & - & + & - & + & - & + & & - & + & & - & + & \\
\hline & & & & & \multicolumn{2}{|c|}{$m g / d a y \pm S D$} & & \multicolumn{2}{|c|}{$m g / d a y \pm S D$} & & \multicolumn{2}{|c|}{$m g / d a y \pm S E$} & \\
\hline $\begin{array}{l}\text { Saturated } \\
\text { dietary fat }\end{array}$ & 24 & 42 & 12 & 14 & $\begin{array}{r}101 \\
\pm 50\end{array}$ & $\begin{array}{r}247 \\
\pm 70\end{array}$ & $\mathrm{p}<0.02$ & $\begin{array}{r}498 \\
\pm 185\end{array}$ & $\begin{array}{r}531 \\
\pm 116\end{array}$ & NS & $\begin{array}{r}598 \\
\pm 181\end{array}$ & $\begin{array}{r}777 \\
\pm 141\end{array}$ & $\mathrm{p}<0.01$ \\
\hline $\begin{array}{l}\text { Unsaturated } \\
\text { dietary fat }\end{array}$ & 41 & 15 & 19 & 8 & $\begin{array}{r}134 \\
\pm 54\end{array}$ & $\begin{array}{r}271 \\
\pm 48\end{array}$ & $\mathrm{p}<0.001$ & $\begin{array}{r}538 \\
\pm 137\end{array}$ & $\begin{array}{r}504 \\
\pm 78\end{array}$ & NS & $\begin{array}{r}671 \\
\pm 140\end{array}$ & $\begin{array}{r}814 \\
\pm 117\end{array}$ & $\mathrm{p}<0.05$ \\
\hline $\begin{array}{l}\text { Statistical } \\
\text { significance } \\
\text { (sat. vs. } \\
\text { unsat.) }\end{array}$ & & & & & NS & NS & & NS & NS & & NS & NS & \\
\hline
\end{tabular}

Total fecal steroid excretion reflected the effects of dietary components on bile acid excretion, being significantly higher when sterol-containing fats were ingested, regardless of the degree of saturation of the dietary fat.

\section{Discussion}

By feeding dietary fats consisting of pure glycerides free of sterols, we have been able to establish in man that the degree of fatty acid saturation per se has an effect on plasma cholesterol concentration independent of any nonglyceride component of the fat. Other authors have reported data indicating

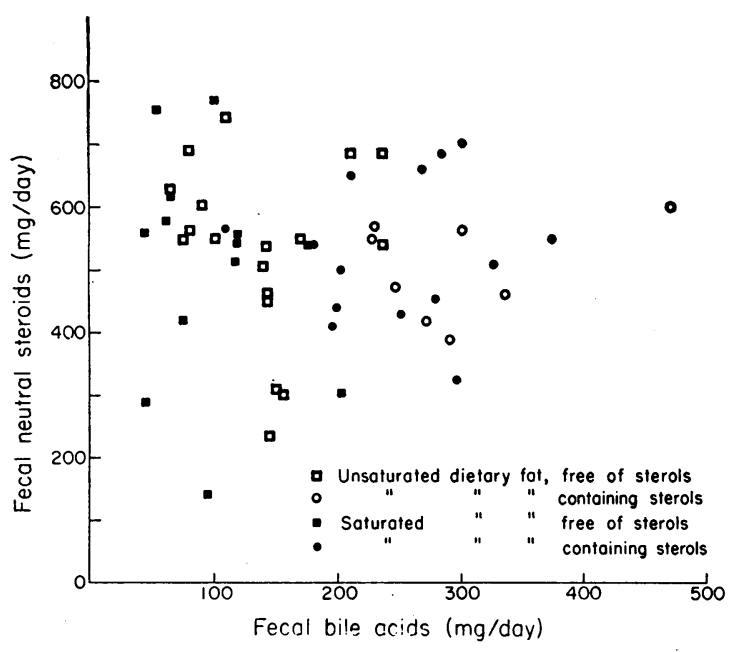

Fig. 3. Relationships Between Fecal excretions OF NEUTRAL STEROIDS AND BILE ACIDS IN 53 STOOL SPECIMENS. that dietary cholesterol (17) and plant sterols (18) may also play a role in the regulation of plasma cholesterol concentration in man. Although the present study does not negate such findings, it establishes that, if nonglycerides play a role, it is in addition to that of the degree of saturation of the fatty acids.

Our data do not establish the relative importance of these factors, but they suggest that, under the conditions of these studies, the fatty acid composition of the dietary fat may be the dominant determinant of the effect of the diet on the plasma cholesterol. In the three subjects who ingested sterolfree fats, their mean cholesterol concentrations in the steady state were 16,26 , and $25 \%$ lower during the ingestion of the unsaturated fat. These changes are somewhat smaller than those previously reported (19) when commercial, sterol-containing fats were exchanged. However, the view that the nonglyceride components of dietary fats play only a minor role in regulating plasma cholesterol concentrations is supported by the finding in the present study in one individual who ingested both commercial and synthetic corn and coconut oils that the cholesterol-altering effect of the two dietary fats was identical.

In addition to establishing a hypocholesterolemic effect for unsaturated dietary fat, these studies further indicate that the change in plasma cholesterol produced need not be accompanied by a reciprocal change in fecal excretion of cholesterol or its metabolic end products. This finding stands in conflict with several others that show an in- 
crease in excretion during the ingestion of unsaturated fat. However, we take issue with those conclusions on methodologic grounds : considering the multiple molecular forms in which both neutral and acidic steroids are excreted in the feces, as well as the confusion created by contaminants in the usual extraction methods, the validity of studies utilizing colorimetric assays (20), titration (21), or charring on glass-paper chromatograms (22) after inadequate preliminary purification steps seems questionable.

Balance studies based on isotopic labeling of cholesterol pools avoid the problems of chemical quantitation; such data from several laboratories have been reported in preliminary form. In a single patient studied in this hospital (2) a marked increase in excretion of neutral sterol seemed to account for most of the change in plasma cholesterol produced by substituting corn oil for butter fat at levels of $40 \%$ of total calories. More recently, Moore, Anderson, Keys, and Frantz (23) reported a similar study with solid diets in five normal young men; no significant changes in acidic or neutral fecal steroids were found in any patient when corn oil replaced butter. However, when all the data were normalized (to correct for different body weights) and then pooled, significant increases in both fecal steroid fractions were found on the corn oil regimen. Avigan and Steinberg (24), on the other hand, using the same general approach with formula diets containing $60 \%$ of calories as fat, found no significant excretion increase in five patients in either fecal steroid fraction. However, in one patient (25) they found a marked decrease in neutral steroid excretion when coconut oil replaced safflower fatty acid esters. Thus, in 10 of 12 studies conducted in our two laboratories it was found that plasma cholesterol changes can occur in the absence of excretion changes; this indicates that some mechanism other than increased loss from the body must be invoked to explain the effects observed in most patients when dietary fats are exchanged.

There are no data available that permit a choice between altered synthesis or redistribution of cholesterol as the mechanism responsible for changes in plasma cholesterol concentrations. The amplitude and rapidity of the plasma changes seem more consistent with the latter possibility, in our view. In our study 4 , for instance, we calculate that the decline in plasma cholesterol content produced by substituting unsaturated for saturated fat would have required a decrease in synthesis from approximately 700 to $150 \mathrm{mg}$ of cholesterol per day during period II, but a return during period III to $700 \mathrm{mg}$ per day. (This estimate is based on the assumption that, during the steady states of periods I and III, cholesterol synthesis equals the excretion of cholesterol and its metabolic products.) It remains for future studies to determine whether endogenous cholesterol synthesis can be so markedly and rapidly altered, and in both directions, and only for a few days after instituting an exchange of dietary fats. Animal studies do not support this explanation of our findings: in rats, cholesterol synthesis has been found increased during ingestion of unsaturated fat $(26,27)$.

Redistribution of plasma cholesterol to other tissues seems entirely plausible. In a normocholesteremic $70-\mathrm{kg}$ male a decrease in cholesterol concentration of $30 \%$ reflects a loss of about $1,500 \mathrm{mg}$ from the plasma compartment. Muscle, bone marrow, adipose tissue, and liver cholesterol pools may total $50 \mathrm{~g}$ in such a man (28), so that a gain or loss of $1.5 \mathrm{~g}$ represents only a $3 \%$ change in these pool sizes. Moreover, certain animal studies lend experimental support for the concept that redistribution from the plasma to other tissues can occur. Avigan and Steinberg (27) showed an increased liver cholesterol content in the rat during the ingestion of unsaturated oils, and Gerson, Shorland, and Adams (29) noted reciprocal changes in plasma and tissue cholesterol contents in the rat when a corn oil regimen replaced a fat-free diet. Most recently, Bieberdorf and Wilson (26) showed an increase in muscle cholesterol in the rabbit as plasma cholesterol concentrations decreased with the administration of an unsaturated oil. Spritz (30) has shown in rabbits that the fatty acid composition of lipoprotein fatty acids influences the transfer rate of isotopic cholesterol in a manner consistent with the concept that unsaturated dietary fat affects plasma cholesterol concentrations by altering equilibria between tissue and lipoprotein cholesterol pools. In contrast to these animal studies, however, Frantz and Carey (31) found no increase in liver cholesterol concentration in man as the plasma concentration was lowered by feeding unsaturated dietary fat. Clinical studies designed to identify other tissues, par- 
ticularly muscle, to which such shifts may occur, are now in progress.

In the present study the degree of saturation of the dietary fat had no detectable effect on steroid excretion, yet the ingestion of plant sterols seemed to cause significant increases in bile acid excretion rates. The reason for this effect, which occurred in the absence of an increase in neutral steroid excretion, is not clear. Wilson (32) has demonstrated in rats that cholesterol feeding leads to increased bile acid excretion; whether a similar effect is produced by other diet sterols in man remains to be determined.

\section{Summary}

In five studies of four patients, fecal excretions of neutral and acidic steroids were measured before, during, and after plasma cholesterol concentrations were altered by exchanges of dietary fats.

Quantitation of the numerous excretion products of endogenous cholesterol was based on chemical isolation of the acidic and neutral steroids, and on measurement of these by titration and by weight, respectively. Completeness of recoveries was verified at all stages, in terms of $\mathrm{C}^{14}$-labeling of the two fractions, after the administration to all patients of $4-\mathrm{C}^{14}$-cholesterol.

Changes in plasma cholesterol content (both increases and decreases) varied from 1,300 to $6,400 \mathrm{mg}$. However, no significant reciprocal changes in excretions of fecal steroids occurred as plasma cholesterol concentrations were made to vary. It seems likely that the immediate changes in plasma concentration were due to redistribution of cholesterol to other tissues.

In three of five studies, sterol-free "synthetic" fats were fed; on saturated and unsaturated fat regimens the degree of saturation exerted a significant effect on plasma cholesterol concentration, independent of nonglyceride components.

Excretion of fecal bile acids was significantly higher when plant sterol-containing fats were fed, as compared to "synthetic" fats of similar fatty acid composition but free of sterols.

\section{References}

1. Spritz, N., S. Grundy, and E. H. Ahrens, Jr. Studies on the mechanism of diet-induced alterations of plasma cholesterol (abstract). J. clin. Invest. 1963, 42, 981.
2. Hellman, L., R. S. Rosenfeld, W. Insull, Jr., and E. H. Ahrens, Jr. Intestinal excretion of cholesterol: a mechanism for regulation of plasma levels (abstract). J. clin. Invest. 1957, 36, 898.

3. Grundy, S. M., E. H. Ahrens, Jr., and T. A. Miettinen. Quantitative isolation and gas-liquid chromatographic analysis of total fecal bile acids. J. Lipid Res. 1965, 6, 397.

4. Miettinen, T. A., E. H. Ahrens, Jr., and S. M. Grundy. Quantitative isolation and gas-liquid chromatographic analysis of total dietary and fecal neutral steroids. J. Lipid Res. 1965, 6, 411.

5. Mangold, H. K. Thin-layer chromatography of lipids. J. Amer. Oil Chem. Soc. 1961, 38, 708.

6. Kelly, R. G., E. A. Peets, S. Gordon, and D. A. Buyske. Determination of $\mathrm{C}^{14}$ and $\mathrm{H}^{3}$ in biological samples by Schöniger combustion and liquid scintillation techniques. Analyt. Biochem. 1961, 2, 267.

7. Craig, L. C., W. Hausmann, E. H. Ahrens, Jr., and E. J. Harfenist. Determination of weight curves in column processes. Analyt. Chem. 1951, 23, 1326.

8. Abell, L. L., B. B. Levy, B. B. Brodie, and F. E. Kendall. A simplified method for the estimation of total cholesterol in serum and demonstration of its specificity. J. biol. Chem. 1952, 195, 357.

9. Goldrick, B., and J. Hirsch. A technique for quantitative recovery of lipids from chromatoplates J. Lipid Res. 1963, 4, 482.

10. Levin, S. J., J. L. Irvin, and C. G. Johnston. Spectrofluorometric determination of total bile acids in bile. Analyt. Chem. 1961, 33, 856.

11. Lindstedt, S., and E. H. Ahrens, Jr. Conversion of cholesterol to bile acids in man. Proc. Soc. exp. Biol. (N. Y.) 1961, 108, 286.

12. Spritz, N., and E. H. Ahrens, Jr. Direct measurement of sterols and bile acids in human feces. Biochemical Problems of Lipids (BBA Library) 1963, 1,66 .

13. Stanley, M. M., and S. H. Cheng. Excretion from the gut and gastrointestinal exchange studied by means of the inert indicator method. Amer. J. dig. Dis. 1957, 2, 628.

14. Whitby, L. G., and D. Lang. Experience with the chromic oxide method of fecal marking in metabolic balance investigations on humans. $\mathrm{J}$. clin. Invest. 1960, 39, 854.

15. Ahrens, E. H., Jr., V. P. Dole, and D. H. Blankenhorn. The use of orally-fed liquid formulas in metabolic studies. Amer. J. clin. Nutr. 1954, 2, 336.

16. Edelman, I. S., and J. Liebman. Anatomy of body water and electrolytes. Amer. J. Med. 1959, 27, 256.

17. Connor, W. E., D. B. Stone, and R. E. Hodges. The interrelated effects of dietary cholesterol and fat upon human serum lipid levels. J. clin. Invest. 1964, 43, 1691.

18. Beveridge, J. M. R., W. F. Connell, and G. A. Mayer. The nature of the substar.ces in dietary 
fat affecting the level of plasma cholesterol in humans. Canad. J. Biochem. 1957, 35, 257.

19. Ahrens, E. H., Jr., J. Hirsch, W. Insull, Jr., T. T. Tsaltas, R. Blomstrand, and M. L. Peterson. The influence of dietary fats on serum lipid levels in man. Lancet 1957, 1, 943.

20. Haust, H. L., and J. M. R. Beveridge. Effect of varying type and quantity of dietary fat on the fecal excretion of bile acids in humans subsisting on formula diets. Arch. Biochem. 1958, 78, 367.

21. Gordon, H., B. Lewis, L. Eales, and J. F. Brock. Dietary fat and cholesterol metabolism. Fecal elimination of bile acids and other lipids. Lancet 1957, 2, 1299.

22. Hamilton, J. G., and J. W. Dieckert. The separation of some bile acids by glass-paper chromatography. Arch. Biochem. 1959, 82, 203.

23. Moore, R. B., J. T. Anderson, A. Keys, and I. D. Frantz, Jr. Effect of dietary fat on the fecal excretion of cholesterol and its degradation products in human subjects (abstract). J. Lab. clin. Med. 1962, 60, 1000.

24. Avigan, J., and D. Steinberg. Metabolism and excretion of cholesterol in man. Fed. Proc. 1959, 18, 5.

25. Avigan, J., and D. Steinberg. Personal communication.
26. Bieberdorf, F. A., and J. D. Wilson. Influence of unsaturated fat on cholesterol- $\mathrm{C}^{\mathbf{1 4}}$ metabolism in the isotopic steady state in the rabbit (abstract). Clin. Res. 1964, 12, 262.

27. Avigan, J., and D. Steinberg. Effects of saturated and unsaturated fat on cholesterol metabolism in the rat. Proc. Soc. exp. Biol. (N. Y.) 1958, 97, 814.

28. Cook, R. P. Cholesterol-Chemistry, Biochemistry and Pathology. New York, Academic Press, 1958, p. 174.

29. Gerson, T., F. B. Shorland, and Y. Adams. The effects of corn oil on the amounts of cholesterol and the excretion of sterol in the rat. Biochem. J. 1961, 81, 584.

30. Spritz, N. Effect of fatty acid saturation on the distribution of the cholesterol moiety of very low density lipoproteins. J. clin. Invest. 1965, 44, 339.

31. Frantz, I. D., Jr., and J. B. Carey, Jr. Cholesterol content of human liver after feeding of corn oil and hydrogenated coconut oil. Proc. Soc. exp. Biol. (N. Y.) 1961, 106, 800.

32. Wilson, J. D. The quantification of cholesterol excretion and degradation in the isotopic steady state in the rat: the influence of dietary cholesterol. J. Lipid Res. 1964, 5, 409. 